\title{
Water and Photosynthetic Rate Flows Under Drought Conditions in a Cork Oak (Quercus suber L.) Forest of Tunisia
}

\author{
Mokhtar Baraket ${ }^{1}$, Sondes Fkiri ${ }^{1}$, Kaoula Nefzi ${ }^{1}$, Sihem Jebbari ${ }^{1}$, Abdelhamid Khaldi ${ }^{1}$ \& Zouhair Nasr ${ }^{1}$ \\ ${ }^{1}$ Laboratory of Management and Valorization of Forest Resources (LR11INRGREF0), National Research \\ Institute of Rural Engineering, Water and Forests, Carthage University, Ariana, Tunisia \\ Correspondence: Mokhtar Baraket, Laboratory of Management and Valorization of Forest Resources \\ (LR11INRGREF0), National Research Institute of Rural Engineering, Water and Forests, Carthage University, \\ Ariana 2080, Tunisia. E-mail: moktar.baraket@gmail.com; mokhtar.baraket@iresa.agrinet.tn
}

Received: November 16, 2019

Accepted: January 19, 2020

Online Published: February 15, 2020

doi:10.5539/jas.v12n3p186

URL: https://doi.org/10.5539/jas.v12n3p186

\begin{abstract}
Relationships between drought, carbon and water fluxes have been rarely studied in south Mediterranean forests. The present research focused on the determination of seasonal and annual water and carbon fluxes of Quercus suber L. forests in northern Tunisia. The methodology was based on the calculation of the standard precipitation index, measurements of trees sap flow and net photosynthesis. Estimations of photosynthesis and transpiration during the 1965-2003 period were used on crop coefficients and water use efficiency terms.

Results indicate a wide evapotranspiration rates fluctuating from $354 \mathrm{~mm} \mathrm{y}^{-1}$ to $784 \mathrm{~mm} \mathrm{y}^{-1}$ with an average value of $553 \mathrm{~mm} \mathrm{y}^{-1}$. Extreme values of the standard precipitation index were -2.4 and +2.7 . The carbon flux ranged from 0.255 to $0.586 \mathrm{~kg} \mathrm{y}^{-1} \mathrm{~m}^{-2}$ with a mean value of $0.448 \mathrm{~kg} \mathrm{y}^{-1} \mathrm{~m}^{-2}$ while average water efficiency reached $0.8 \mathrm{gr} \mathrm{C} \mathrm{kg}^{-1} \mathrm{H}_{2} \mathrm{O}$. Despite the fact, that there is a significant difference between the four studied sites and important annual variability of carbon fluxes, the correlations between water and carbon fluxes and drought index were very low. The results clearly indicate that deep transformations are occurring in the Quercus suber L. forests, as a result of carbon dioxide fertilization being cancelled by the drought effect.
\end{abstract}

Keywords: Quercus suber L., draught, net photosynthesis, evapotranspiration, mediterranean forests

\section{Introduction}

Global climatic models predict a change in rainfall pattern in Tunisia, characterized mainly by a decrease in summer rainfall coupled with greater inter-seasonal and inter-annual variability (IPCC, 2007; Hulme et al., 2001) These previsions for the near future reveal an accentuation of the drought, which means that increasingly longer and more intense dry periods to be expected (Giannkopoulos et al., 2005). The dry period of the year and the succession of two or more dry years would be greater when compared to the reference period (Nasr et al., 2008).

The study of the climate during the last century showed that drought remains a recurring and cyclical phenomenon in Tunisia (Benzarti, 1994). In fact, $50 \%$ of dry years were located in North of Tunisia where the climate is mostly humid. Severity of draught is dominated in and it is dispersed within the same region. Hajri (1996) showed that driest years occurred in the 1940s. However, in the 1960s it was more likely of the local type. The phenomenon of the isolated dry year is the most common in Northern Tunisia; it occurred $48 \%$ to $66 \%$ of the observed period. During the period 1985-1997, the succession of three consecutive dry years was recorded only in Beja province (1987-1990), but no succession of four consecutive dry years has been ever recorded. It is good to notice that the North-West Tunisia area is an important reserve of water and biodiversity. The Quercus Suber L. Forest is one of the most fragile ecosystems in this region. This forest has been an alarming deterioration, it now occupies an area of 90000 hectares against 140,000 hectares 100 years ago (Boudy, 1952). However, it still offers several goods and services to society mainly the photosynthesis carbon capture insured by these forming trees which are threaten by the expected drought and the alteration of water and carbon flows.

The determination and modeling of water and carbon flows have shown the complexity of the exchanges between both forest and atmosphere (Le Dantec et al., 2000; Davi, 2000). These predictive models usually require a lot of data and observations (Dewar, 1992; Granier et al., 2000) of daily weather, soil and vegetation which are often unavailable. In this study, a simple approach based on accurate measurements of 
evapotranspiration and photosynthesis for a full year and a historical simulation that assumes the consistency of water efficiency and crop coefficient were proposed. The main objectives are both the seasonal determination of flows and their simulation during the period 1965-2003.

\section{Material and Methods}

\subsection{Study Site}

The Tunisian cork oak (Quercus suber L.) forest is located on the northwest border of the country. It belongs to the humid and sub-humid bioclimatic stage (Figure 1). It is characterized by Mediterranean climate with four seasons where rainfall is mainly concentrated in autumn and winter and dry spring and summer. The maximum precipitations were $1550 \mathrm{~mm}$ and the isohyets indicated a strong NE-SW gradient. The landscape of the Kroumerie-Mogods region is typically that of a mountain forest with persevering hardwoods $(43 \%)$, conifers $(8 \%)$, maquis and scrubland (49\%).

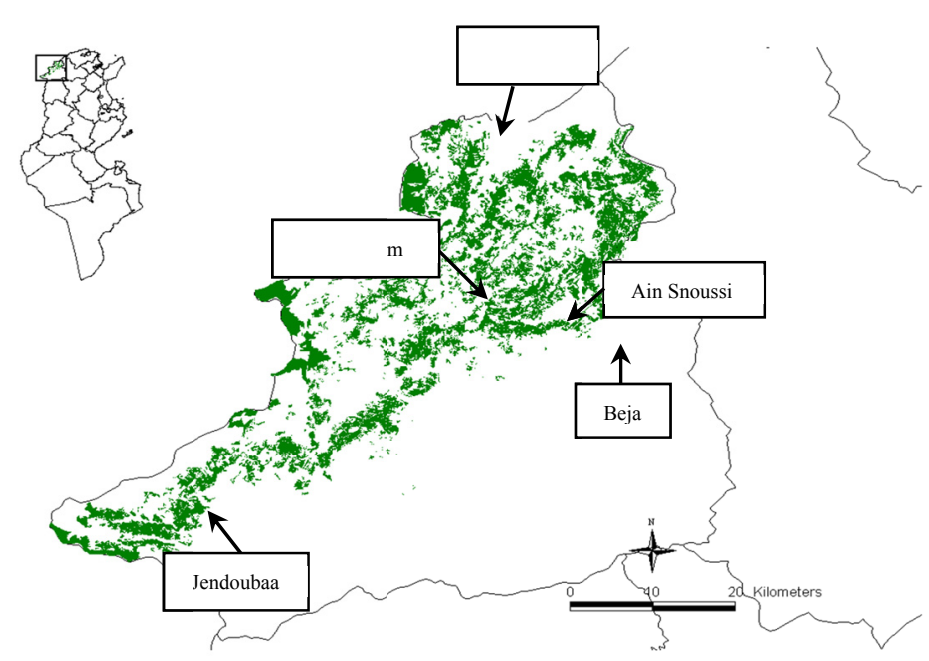

Figure 1. Geographical location of the Tunisian Suberie: experimental site and meteorological stations

The experimental site for the present study was located in Ain Snoussi forest (Lat N: $36^{\circ} 52^{\prime}$, Long E: $8^{\circ} 57^{\prime}$ and Alt: $640 \mathrm{~m}$ ). This site belongs to the moisture cool winter bioclimatic stage. The average rainfall and temperature were, respectively, $1120 \mathrm{~mm}$ and $15.2{ }^{\circ} \mathrm{C}$. The reference evapotranspiration estimated by the FAO-Penman formula is ETo $=1100 \mathrm{~mm}$. The density of this forest varied greatly from 150 to 400 trees ha ${ }^{-1}$. The soil is loam and rather deep with limited water reserves, $\operatorname{Pf}(0.3)=15 \%$; $\operatorname{Pf}(4.2)=28 \%$; Bulk density, ds $=1.35$. A plot of $30 \mathrm{~m} \times 30 \mathrm{~m}$ oriented south-east was chosen. The perimeters of trees measured at $1.30 \mathrm{~m}$ from the ground vary from 70 to $130 \mathrm{~cm}$. The average height of the trees was $10.3 \pm 1.2 \mathrm{~m}$. The undergrowth is dominated by annuals and some shrubs. Vegetation cover was estimated at $78 \%$ during the wet season and $42 \%$ in the dry season. Eight trees, two per diameter class were chosen to measure sap flow and photosynthesis during the 2008 and 2009 season.

\subsection{Measurements and Treatment of Climate Data}

In Ain Snoussi, a HOBO weather station provides continuous measurements of air and soil temperatures $\left({ }^{\circ} \mathrm{C}\right)$, solar radiation $\left(\mu \mathrm{mol} \mathrm{m} \mathrm{m}^{-2} \mathrm{~s}^{-1}\right.$ ), wind speed and direction $\left(\mathrm{ms}^{-1}\right.$ and degree), relative humidity $(\%)$. An appropriate computer program allows calculation of sap flow as well as reference evapotranspiration $\left(\mathrm{ETo}, \mathrm{mm} \mathrm{j}^{-1}\right)$ using the FAO formula (Allen et al., 1996).

Historical temperature and precipitation data for representative forest stations (Table 1); Beja (BJA), Jendouba (JND), Ain Drahem (ADH) and Tabarka (TAB) were collected from the database of the National Institute of Meteorology of Tunis for the period 1965-2003. The temperature data (min and max) were used to calculate the reference evapotranspiration (Allen et al., 1996). The monthly precipitation was used to estimate the drought Index, SPI (Standard Precipitation Index) defined by McKee et al. (1993). 
Table 1. Geographical Characteristics, temperature $\left({ }^{\circ} \mathrm{C}\right)$ and mean precipitations $(\mathrm{mm})$ of stations during the period 1961-1990

\begin{tabular}{lllllll}
\hline Stations & Lat N & Long E & Alt $(\mathrm{m})$ & Tn $\left({ }^{\circ} \mathrm{C}\right)$ & Tx $\left({ }^{\circ} \mathrm{C}\right)$ & Rainfall $(\mathrm{mm})$ \\
\hline ADH & $36^{\circ} 47^{\prime}$ & $8^{\circ} 43^{\prime}$ & 715 & 10.6 & 17.9 & 1488 \\
BEJ & $36^{\circ} 44^{\prime}$ & $9^{\circ} 11^{\prime}$ & 360 & 10.5 & 23.9 & 557 \\
TAB & $36^{\circ} 57^{\prime}$ & $8^{\circ} 45^{\prime}$ & 166 & 13.1 & 22.9 & 961 \\
JND & $36^{\circ} 29^{\prime}$ & $8^{\circ} 48^{\prime}$ & 143 & 11.1 & 25.2 & 460 \\
\hline
\end{tabular}

\subsection{Measurement of Sap Flow, Photosynthesis and Soil Moisture Content}

Four trees were equipped with thermal sensors to continuously heating Granier. Tree diameters were between 20 and $40 \mathrm{~cm} .2 \mathrm{~cm}$ deep is too shallow even after bark removal. Needles 5 and $10 \mathrm{~cm}$ long are available. The sensors were protected against radiation by an aluminum film. An acquisition unit type $\Delta \mathrm{T}$ (DL2 ${ }^{\text {-e }}$ ) continuously (every $30 \mathrm{sec}$ ) measures signals that are averaged over 1 hour and stored in memory. The calibration equation established by Granier (1987) was used to calculate flow density;

$$
S F d=136.828 K^{1.2997}
$$

The index K of flux calculated by the formula;

$$
K=\frac{d T_{o}-d T}{d T_{o}}
$$

Where, $S F_{d}$ : flow density $\left(10^{-6} \mathrm{~m} / \mathrm{s}\right)$; $d T_{o}$ : temperature different $\left({ }^{\circ} \mathrm{C}\right)$ when flow is zero, late night in wet period; $d T$ : temperature difference for a positive flow density $\left({ }^{\circ} \mathrm{C}\right)$.

An empirical relationship established in the study area connecting the tree diameter (DBh) to the sapwood section $\mathrm{Sa}(\mathrm{r}=0.65)$ by core sampling was used to calculate the daily flow;

$$
S a=1.058 D B h^{1.2889}
$$

The average transpiration of the trees $\left(\mathrm{Tr}, \mathrm{mm} \mathrm{j}^{-1}\right)$ was calculated by weighting the DBhi of the tree $\mathrm{i}$. The total daily flow was found by integrating the hourly flows and weighting by the diameters of the trees.

$$
\frac{\sum_{i=1}^{i=4} S F D i \times D B H i}{\sum_{i=1}^{i=4} D B H i}
$$

Soil water content was measured monthly by a TDR30 at depths of 10 and $30 \mathrm{~cm}$ at eight points, thus integrating the undergrowth cover. A simplified water balance was calculated on the $0-40 \mathrm{~cm}$ layer based on the soil field capacity value and precipitation recorded at the same site.

$$
\Delta S=E s+P-D \pm R
$$

Soil water content was measured monthly by a TDR30 at two depths $(10$ and $30 \mathrm{~cm})$ at eight points, thus integrating the undergrowth cover. A simplified water balance was determined on the $0-40 \mathrm{~cm}$ layer based on the soil field capacity value and precipitation recorded at the same site.

The measurements of net photosynthesis were carried out on the eight trees chosen, for a full year by choosing to make these measurements in 5 typical days of each season of the year.. Net photosynthesis was measured by a Li-COR6400 device (Nebraska, USA) on the 4th leaf of young twigs, one from each orientation (North and South) (Nasr et al., 2012). The measurements included sun lit leaves (Pns), leaves in the shade (Pno) and dark respiration measurements $(\mathrm{Rn})$. The total resulting was then calculated assuming equal leaf surfaces in the sun and leaves in the shade, such as:

$$
P n=\frac{P n s+P n o}{2}+R n
$$

\subsection{Estimates of Seasonal Photosynthesis During the Climatic Period 1965-2003}

Seasonal values of water efficiency, $\mathrm{EUE}=\mathrm{Pn} / \mathrm{Tr}$ and evapotranspiration coefficients, $\mathrm{KT}=\mathrm{Tr} / \mathrm{ETo}$ and $\mathrm{KTo}=$ $(\mathrm{Tr}+\mathrm{Es}) /$ ETo were determined from the measurements made in the station of Ain Snoussi during the year 2008-2009. These values of EUE, KT and K To have been adapted after adjustment for the BJA, ADH, TAB and JND stations by a ratio of the vapor pressure deficits between that of Ain Snoussi and those of the other stations for the 2008-2009 periods. This assumes that the $\mathrm{CO}_{2}$ and $\mathrm{H}_{2} \mathrm{O}$ gas exchanges are essentially controlled by the stomatal conductance via the vapor air pressure deficit. These seasonal ratios ranged from 0.31 to 1.19 . Thus, from the monthly temperature and precipitation data for the 1965-2008 periods, the terms SPI, ETo, ET and Pn have been calculated for each season and each station. 


$$
\begin{aligned}
& P \succ K_{T o} . E T_{o} \Rightarrow E T=K_{T o} . E T_{o} \\
& P \leq K_{T_{o}} \cdot E T_{o} \Rightarrow E T=P \\
& P_{n}=E U E \cdot K_{T} \cdot E T_{o}
\end{aligned}
$$

\subsection{Statistic Analysis}

SAS GLM procedure was performed for all collected data using the. The comparison of averages was performed by The Newman-Keuls test at the $5 \%$ risk threshold.

\section{Results}

\subsection{Seasonal Photosynthesis and Evapotranspiration Values}

Seasonal mean values of tree transpiration (Tr) and evapotranspiration of the undergrowth (Es) showed that maximum values were reached in spring being $1.4 \mathrm{~mm} / \mathrm{d}$ and $1.3 \mathrm{~mm} / \mathrm{d}$, respectively (Figure 2). There was also a significant decrease in term of evapotranspiration and a slight decrease in tranpiration amounts during the summer season. It was recorded that annual water consumption of trees was $342 \mathrm{~mm}$ and evapotranspiration of undergrowth was $192 \mathrm{~mm}$. For the growing season March-October, the tree transpiration (from trees sap flow) and the evapotranspiration (from soil water content variation) of the undergrowth were about $308 \mathrm{~mm}$ and 80 $\mathrm{mm}$, respectively.

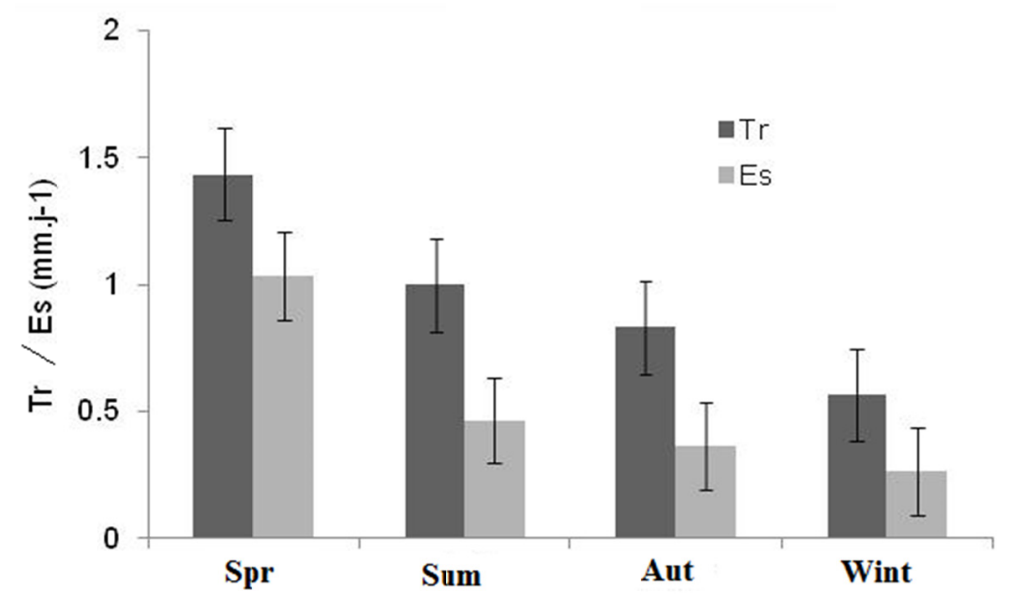

Figure 2. Seasonal evolution of tree transpiration and evapotranspiration of the undergrowth measured in a cork oak forest in northern Tunisia (2008-2009)

The highest values of the net photosynthesis were recorded in spring, with a mean value of $9 \mu \mathrm{mol} \mathrm{m} \mathrm{m}^{-2} \mathrm{~s}^{-1}$ for leaves in the sun in comparison with $4.3 \mu \mathrm{mol} \mathrm{m} \mathrm{m}^{-2} \mathrm{~s}^{-1}$ for those in the shade (Figure 3). During the dry season, there was a significant decline in net photosynthesis. Hereafter, net photosynthesis has increased significantly following probably the autumn rains to fall in winter as a consequence of lower temperature. Furthermore, nighttime breathing was maximal in summer, lowest in winter and average in autumn. The recorded values did not exceed (-2) $\mu \mathrm{mol} \mathrm{m} \mathrm{m}^{-2}$. 


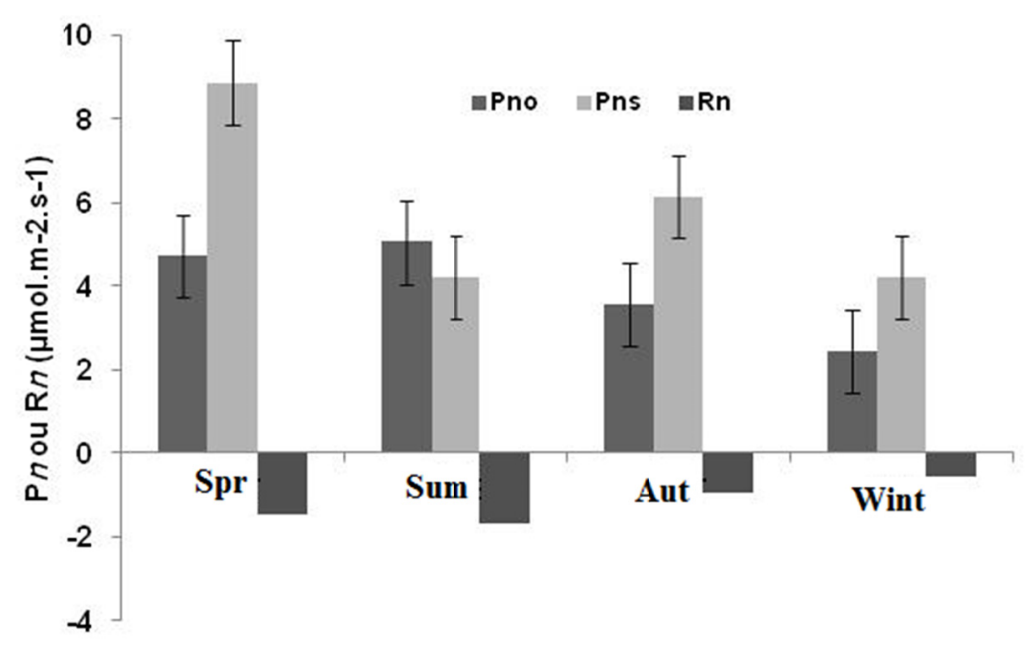

Figure 3. Seasonal values of Pno, Pns and Rn in a cork oak forest in northern Tunisia (2008-2009)

\subsection{Historical Analysis of Drought and Seasonal Flows in 1965-2003}

The estimation of drought by SPI showed very few wet years, 2 years at ADH. Normal years were dominant in $65 \%$ of cases (Table 2). However, we can note that a number of very dry years are more than very wet ones. Then, we showed an asymmetry between the numbers of dry and wet years which the percentages varied from 9 to $20 \%$.

Table 2. Percentage of dry and wet years according to the SPI drought index for the 4 stations (TH: very wet year, $\mathrm{H}$ : wet year, N: normal year, S: dry year)

\begin{tabular}{llllll}
\hline Stations & TH $(\mathrm{Spi}>2)$ & $\mathrm{H}(1<\mathrm{Spi}<2)$ & $\mathrm{N}(-1<\mathrm{Spi}<1)$ & $\mathrm{S}(\mathrm{Spi}<-1)$ & $\mathrm{TS}(\mathrm{Spi}<-2)$ \\
\hline TAB & 0 & $20 \%$ & $65 \%$ & $12 \%$ & $3 \%$ \\
ADH & $2 \%$ & $9 \%$ & $67 \%$ & $14 \%$ & $5 \%$ \\
JDB & 0 & $14 \%$ & $67 \%$ & $19 \%$ & 0 \\
BJA & 0 & $18 \%$ & $64 \%$ & $18 \%$ & 0 \\
\hline
\end{tabular}

The analysis of simulated $\mathrm{Fc}$ fluxes showed to be greater in autumn and spring comparing to winter with the summer flows being the lowest (Figure 4). Summer fluxes are also the least variable from year flow to another. The most variable flows are those of the winter season where we note an increase in the carbon flux during mild winters such as 1987 or 2001. Furthermore, there was a slight upward trend in spring and autumn flows that started especially since the warming period of 1975. 


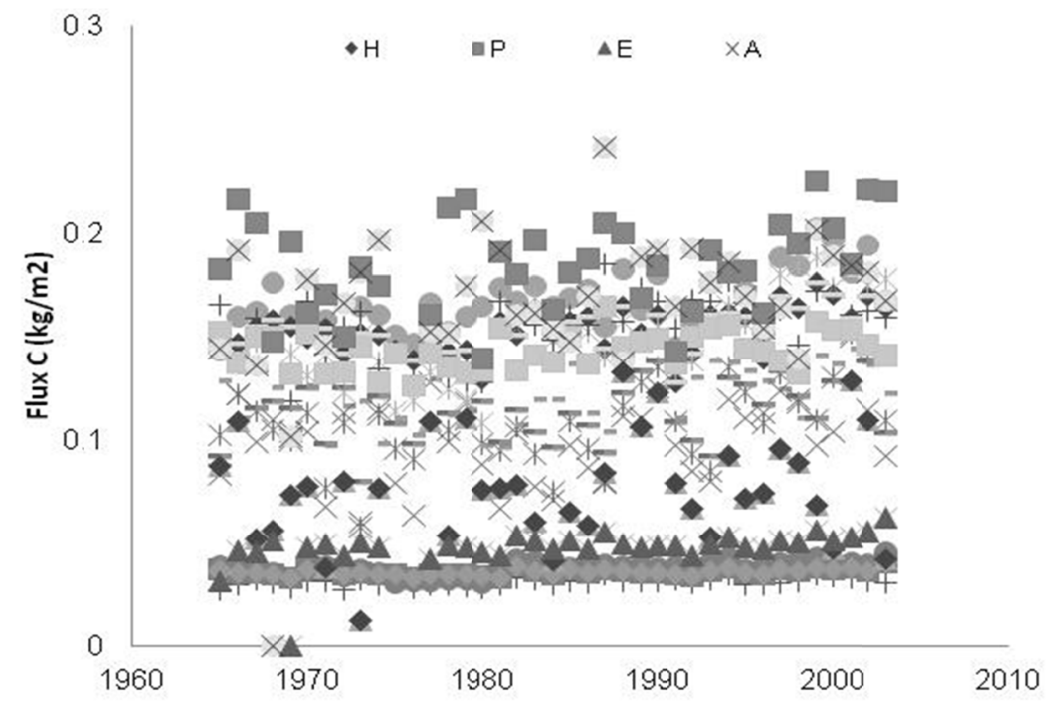

Figure 4. Simulated values of seasonal carbon fluxes (A: autumn, E: summer, H: winter, P: spring) for ADH, $\mathrm{BEJ}, \mathrm{TAB}$ and JEN during the 1965-2003 simulation period. Ilm faut faire chaque station à part

\subsection{Statistical Analysis of Tr, Fc and SPI Parameters in 1965-2003}

For the different stations evaluated, Initial evapotranspiration $\left(\mathrm{ET}_{0}\right)$ varied from $354 \mathrm{~mm}_{\text {year }}{ }^{-1}$ to $784 \mathrm{~mm}$ year $^{-1}$ with an average value of $553 \mathrm{~mm}$ year $^{-1}$. The SPI values ranged from -2.4 to +2.7 and a variation of $\mathrm{Fc}$ from 0.255 to $0.586 \mathrm{~kg} \mathrm{an}^{-1} \mathrm{~m}^{-2}$ was recorded with an average $0.448 \mathrm{~kg} \mathrm{an}^{-1} \mathrm{~m}^{-2}$. The water use efficiency reached 0.8 gr $\mathrm{C} \mathrm{kg}^{-1} \mathrm{H}_{2} \mathrm{O}$, which was slightly higher during a dry year (Table 3 ).

Table 3. Analysis of Fc, ET and SPI averages for DHA, BEJ, TEB and JEN stations during the period 1965-2003

\begin{tabular}{llllll}
\hline Variable & Mean & SD & Sum & Min & Max \\
\hline Fc & 0.45 & 0.047 & 69 & 0.25 & 0.59 \\
ET & 1.5 & 0.35 & 233.4 & 0.95 & 2.15 \\
SPI & -0.005 & 1 & -0.8 & -2.41 & 2.7 \\
\hline
\end{tabular}

The GLM and SNK analysis indicated for Fc that the ADH station showed the highest mean comparing to the stations from BJA, TAB and JEN, but no significant differences between the other stations was recorded (Table 4). For Tr value, two groups can be distinguished, one with BEJ and ADH stations, the other with TAB and JEN stations (Table 5).Whereas, for the SPI index, no significant effect was recorded between the stations.

Table 4. Analysis of Fc, ET and SPI averages for DHA, BEJ, TEB and JEN stations during the period 1965-2003

\begin{tabular}{llllll}
\hline Variable & DDL & Sum of Square Mean & Square Mean & Value F & $\operatorname{Pr}>\mathrm{F}$ \\
\hline Fc & 3 & 0.04611361 & 0.0153712 & 7.92 & $<0.0001$ \\
ET & 3 & 12.2891453 & 4.09638178 & 104.1 & $<0.0001$ \\
SPI & 3 & 0.0359695 & 0.01198565 & 0.01 & 0.9983 \\
\hline
\end{tabular}


Table 5. SNK analysis of the Fc, SPI and ET parameters for the ADH, TAB, BEJ and JEN stations during the period 1965 and 2003

\begin{tabular}{llll}
\hline Variable & SNK group & Mean & Station \\
\hline & A & 0.47573 & ADH \\
Fc & BB & 0.44859 & JEN \\
& BB & 0.44082 & TAB \\
B & 0.42797 & BEJ \\
ET & AA & 1.80641 & BEJ \\
& AB & 1.79514 & ADH \\
& B & 1.26179 & TAB \\
SPI & AA & 1.21231 & JEN \\
& AA & 0.01128 & ADH \\
& AA & 0.00256 & TAB \\
& A & -0.00474 & BEJ \\
\hline
\end{tabular}

Positive correlations between ET and Fc and low negative correlations with SPI were observed. It is evident that a significant station effect was present for the $\mathrm{Fc}$ and ET variables but no significant station effect at the 5\% threshold for the SPI variable was found (Table 6).

Table 6. Correlations between the Fc, SPI and ET parameters for the ADH, TAB, BEJ and JEN stations during the period 1965 and 2003

\begin{tabular}{llll}
\hline & Fc & SPI & ET \\
\hline Fc & 1.000 & -0.0876 & 0.456 \\
SPI & -0.0876 & 1.000 & -0.01023 \\
ET & 0.456 & -0.01023 & 1.000 \\
\hline
\end{tabular}

\subsection{Evolutions of Fc and SPI in 1965-2003}

From the results presented in Figure 5, it can be observed that there is certain cyclist of photosynthesis as well as for drought. On an annual scale, the synchronization between SPI and Fc is not established; in some cases it is even reversed. There is a clear downward trend in photosynthesis during major dry periods, such as that of 1987-1993. The lowest variation of Fc was recorded in JND, the highest one in ADH, while TAB and BJA were overall similar. 

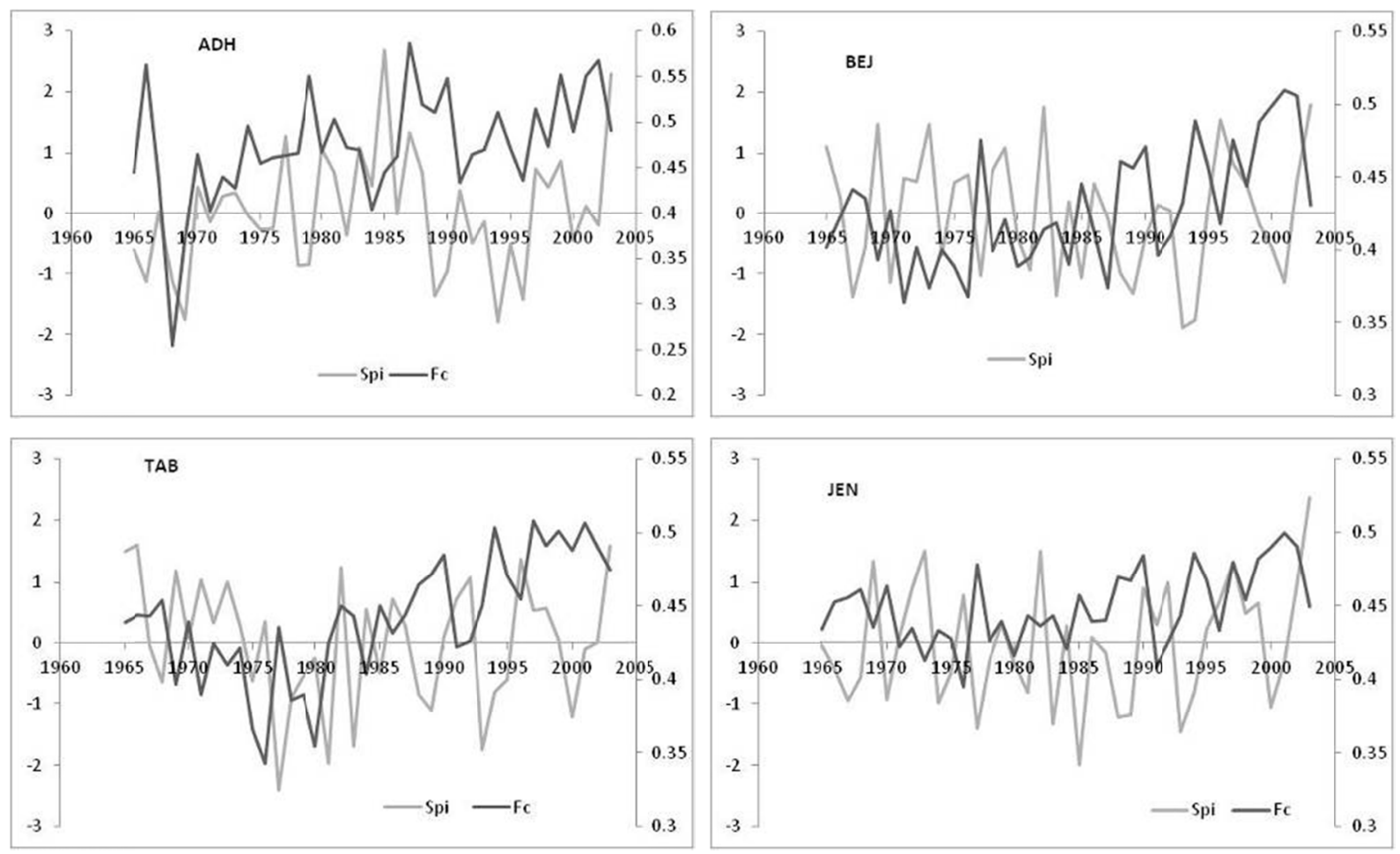

Figure 5. Variations in annual SPI and $\mathrm{Fc}$ values for $\mathrm{BJA}, \mathrm{ADH}, \mathrm{TAB}$ and JND stations during the period 1965-2003

\section{Discussion}

The physical errors in the estimation of sap flow by the Granier sensor have been widely discussed in the literature. They can be caused by the representation of the measurement according to the orientation and depth of the probes (Nasr et al., 2012). Our measurements were made at a depth of $2 \mathrm{~cm}$ assuming that most of the water flow passes through this slice. Thus, the South-East orientation chosen cannot represent the average of the flows. Poyatos et al. (2007) showed that $85 \%$ of the fluxes pass close to the cambium and a lower contribution of the heartwood. On Quercus ilex, Infante et al. (2007) used the Granier technique and showed a fairly large flux variation of 2 to $3.5 \mathrm{~L} \mathrm{dm}^{-2} \mathrm{~h}^{-1}$ depending on the orientation.

Repetitive measurements of the net photosynthesis at the foliar scale on eight trees may not represent the average carbon fluxes of the forest. Indeed, the variability of measurements between trees, orientations and leaves was very important. The coefficient of variation has in some cases exceeded $50 \%$.

Despite these sources of multiple errors, the average values of tree transpiration, soil evapotranspiration and net photosynthesis are quite comparable to the values observed in the Mediterranean forests. According to Tognetti et al. (1998), Quercus ilex sap fluxes were in the order of $50 \mathrm{~L} \mathrm{j}^{-1}$ with a maximum hourly flux of $3 \mathrm{~L} \mathrm{hr}^{-1}$. Furthermore, Vincke et al. (2005) from sap flow measurements showed that declining trees responded to fluctuations in climate demand but their transpiration remained low and less than $1 \mathrm{~mm} / \mathrm{d}$. Under these conditions, the herbaceous layer can consume more water than the trees, up to $2.9 \mathrm{~mm} /$ day.

Using the flux method (Eddy covariance) on a $38 \%$ mixed forest (Q. robur/Q. petraea) and $31 \%$ Scots pine, Gerricle et al. (2005) estimated a primary productivity of $630 \mathrm{~g} \mathrm{C} \mathrm{m}^{-2} \mathrm{an}^{-1}$. In the same context, Periera et al. (2007) estimated by the eddy covariance in oak forest in Portugal that a primary productivity varied between 500 and $1000 \mathrm{~g} \mathrm{C} \mathrm{m}^{-2} \mathrm{an}^{-1}$. While, Wilkinson et al. (2012) obtained higher flows in the order of $1500 \mathrm{~g} \mathrm{~m}^{-2}$ year ${ }^{-1}$ during the period 1999-2010 in a forest of Fraxinus and Quercus robur. The annual phytomass of Ain Snoussi Forest was evaluated at $5.98 \mathrm{~T} \mathrm{ha}^{-1}$ year $^{-1}$ (Sebei et al., 2004), which equates to $0.29 \mathrm{~kg} \mathrm{of} \mathrm{C} \mathrm{m}^{-2}$ year $^{-1}$.

Several authors have also highlighted the effects of drought on the carbon balance of forests. In fact, Breda et al. (2006) was able to show the consequences of an extreme event (drought in 2003) on typical Mediterranean stands. The low water availability of the soil in summer resulted in a very low carbon balance associated with low carbohydrate accumulations in the trunks. 
For the simulations made, it was assumed that the ET/ETo and $\mathrm{Pn} / \mathrm{Tr}$ ratios are constant from one year to another, as well as a constant value of the leaf area index (Lai) was assumed. This hypothesis remains valid for the leaf surface unit, but it did not allow the spatial integration of the simulated values. According to Davi et al. (2008), although the Lai varied slightly, it remained the main variable controlling both water and carbon flows and also the relationship between this parameter and the density for a Mediterranean forest of Quercus ilex and Pinus halepensis. Additionally, the control mechanisms for canopy transpiration are mainly stomatal regulation, hydraulic conductance and leaf area adjustment. The decrease in leaf area appears as the main mechanism for adjusting transpiration to new water conditions (Limosin, 2009) in Quercus ilex species.

During the period 1965-2003, the rate of atmospheric $\mathrm{CO}_{2}$ had to increase approximately from $260 \mathrm{ppm}$ to 380 ppm. This enrichment did not cause a net increase in calculated carbon fluxes. As if drought have counterbalanced the fertilizing effect of atmospheric carbon. However, in a controlled environment, it was previously highlighted that the effect of carbon enrichment on oak by an increase in the net photosynthesis capacity (Vivin \& Gehl, 1997).

\section{Conclusions}

The simulations carried out showed evapotranspiration flux ranging from 0.95 to $2.15 \mathrm{~kg} \mathrm{~m}^{-2} \mathrm{~d}^{-1}$ wile photosynthesis flux ranged from 0.255 to $0.586 \mathrm{~kg} \mathrm{~m}^{-2}$ year $^{-1}$, SPI were -2.41 and 2.69 for a dry and wet year, respectively.

These simulations showed some inter annual variability of flows with a special site effect. However, synchronization with the climatic drought by the SPI index has not been established. In addition to this variability, it was not possible to observe clearly a trend upward or downward flows, but rather certain cyclicality was clearly noticed.

\section{Acknowledgements}

The authors acknowledge helpful funding from the European Union Horizon 2020 programme, under Faster project, grant agreement $\mathrm{N}^{\circ}[810812]$. The authors would like to gratefully acknowledge all the members of management laboratory and valorization of forest resources, National research Institute of rural engineering, Water and Forests (INRGREF), for providing the Laboratory facilities to carry out this work and for their suggestions.

\section{References}

Allen, M. R., \& Robertson, A. W. (1996). Distinguishing modulated oscillations from coloured noise in multivariate datasets. Climate Dynamics, 12(11), 775-784. https://doi.org/10.1007/s003820050142

Allen, M. R., \& Smith, L. A., \& Monte Carlo, S. S. A. (1996). Detecting irregular oscillations in the presence of coloured noise. J. Clim., 9, 3373-3404. https://doi.org/10.1175/1520-0442(1996)009\%3C3373:MCSDIO\%3 $\mathrm{E} 2.0 . \mathrm{CO} ; 2$

Barbaroux, C. (2002). Analyse et modélisation des flux de carbone de peuplements forestiers pour la compréhension de la croissance de deux espèces feuillues Quercus petraea et Fagus sylvatica (Thèse de doctorat en Terre, océan, espace, Université Paris XI-Orsay, France).

Benzarti, Z. (1994). Les variations interannuelles de la pluviométrie en Tunisie, In La Variabilité du Climat et l'homme en Tunisie (pp. 63-83). GREVACHOT, Université de Tunis.

Boudy, P. (1952). Guide forestier de l'Afrique du Nord. La maison rustique (Paris 6, p. 26).

Boussnina, A. (1986). La variabilité des pluies en Tunisie (Faculté des Sciences Humaines et Sociales $2^{\circ}$ Série Géographie Vol. 22).

Bréda, N., Huc, R., Granier, A., \& Dreyer, E. (2006). Temperate forest trees and stands under severe drought. Annals Forest Sciences, 63, 625-644. https://doi.org/10.1051/forest:2006042

Davi, H. (2000). Utilisation d'un modèle de flux de carbone et d'eau en milieu forestier méditerranéen. Applications aux couverts de chêne vert (Quercus ilex) et de chêne pubescent (Quercus pubescens). DEA d'Ecologie, Filière Ecologie Fonctionnelle, Université Paris-Sud XI, Orsay, France.

Davi, H., Baret, F., Huc, R., \& Dufrêne, E. (2008). Effect of thining on LAI variance in heterogeneous forests. Forest Ecololgy and Management, 256, 890-899. https://doi.org/10.1016/j.foreco.2008.05.047

Dewar, R. C. (1997). A simple model of light and water use evaluated for Pinus radiata. Tree Physio, 17, 259-265. https://doi.org/10.1093/treephys/17.4.259

Giannkopoulos, C., Bindi, M., Moriondo, M., Lesager, L., \& Tin, L. (2005). Climate change impacts in the 
Mediterranean resulting from $2{ }^{\circ} \mathrm{C}$ global temperature rise. A report for WWF.

Granier, A. (1987). Evaluation of transpiration in a Douglas-first and by means of sap flow measurements. Tree Physiology, 3(4), 309-320. https://doi.org/10.1093/treephys/3.4.309

Granier, A., Loustau, D., \& Bréda, N. (2000). A generic model of forest canopy conductance dependent on climate, soil water availability and leaf area index. Annals of Forest Sciences, 57, 755-765. https://oi.org/10.1051/ forest:2000158

Guerric, L. M., Hendrik, D., Soudani, K., François, C., Le Dentec, V., \& Dufrêne, R. (2005). Modeling annual production and carbon fluxes of a large managed temperate forest using forest inventories, satellite data and field measurements. Tree Physiology, 25, 859-872. https://doi.org/10.1093/treephys/25.7.859

Hajri, J. (1996). La Sécheresse Climatique en Tunisie. In L. Henia (Eds.), La variabilité climatique et l'homme en Tunisie (pp. 187-201). GREVACHOT, Colloque VI, Faculté des Sciences Humaines et Sociales de Tunis.

Hulme, M., Doherty, R., Ngara, T., New, M., \& Lister, D. (2001). African Climate Change: 1901-2100. Climate Research, 17, 145-68. https://doi.org/10.3354/cr017145

Infante, J. M., Mauchamp, A., Fernandez-Ales, R., Joffre, R., \& Rambal, S. (2007). Within tree variation in transpiration in isolated evergreen Oak trees: Evidence in support the pipe model theory. Tree Physiology, 21, 409-414. https://doi.org/10.1093/treephys/21.6.409

IPCC (Intergovernmental Panel on Climate Change). (2001). Climate Change 2001: The Scientific Basis. Contribution of Working Group I to the third assessment report of the IPCC. Cambridge University Press, Cambridge.

IPCC (Intergovernmental Panel on Climate Change). (2007). In S. Solomon et al. (Eds.), Climate Change 2007: The Scientific Basis. Contribution of Working Group I to the Fourth Assessment Report of the Intergovernmental Panel on Climate Change. Cambridge Univ. Press, New York.

Le Dantec, V., Dufrêne, E., \& Saugier, B. (2000). Inter annual and spatial variations of maximum leaf area index in temperate deciduous stands. Forest Ecology Management, 134, 71-81. https://doi.org/10.1016/S0378-1127 (99)00246-7

Lee, S. H., Woo, S. Y., Nasr, Z., Zineddine, M., Khaldi, A., \& Rejeb, M. N. (2011). Can net photosynthesis and water relations provide a clue on the forest decline of Quercus suber in North Tunisia? African Journal of Biotechnology, 10(9), 1637-1639. https://doi.org/10.5897/AJB10.2026

Limosin, J. M. (2009). Vulnérabilité du chêne vert (Quercus ilex L.) à une augmentation de la sécheresse: Quels ajustements fonctionnels? (Thèse Montpellier SupAgro, France).

McKee, T. B., Doesken, N. J., \& Kleist, J. (1993). The relationship of drought frequency and duration to time scales (pp. 179-184). Preprints, 8th Conference on Applied Climatology, January 17-22, Anaheim, California, USA.

Nasr, Z., Almohammed, H., Gafrej, R., Maag, C., \& King, L. (2008). Drought modeling under climate change during the 2020 and 2050 periods. - Options Méditerranéennes Series A, 80: 365-369

Nasr, Z., Woo, S. Y., Zineddine, M., Khaldi, A., \& Rejeb, M. N. (2011). Sap flow estimates of Quercus suber according to climatic conditions in north Tunisia. African Journal of Agricultural Research, 6(20), 4705-4710. https://doi.org/10.5897/AJAR10.869

Nasr, Z., Zineddine, M., Khaldi, A., Woo, S. Y., Nouri, M., Khorchani, A., .. Rejeb, M. N. (2012). Seasonal variations of evapotranspiration and net carbon assimilation in a cork oak forest of North Tunisia. Integrated Protection in Oak Forests. IOBC/WPRS Bulletin, 76, 43-46.

Pereira, J. S., Mateus, J. A., Aires, L. M., Pita, G., Pio, C., David, J. S., ... Rodrigues, A. (2007). Net ecosystem carbon exchange in three contrasting Mediterranean ecosystems-The effect of drought. Biogeosciences, 4, 791-802. https://doi.org/10.5194/bg-4-791-2007

Poyatos, R., Llorens, P., \& Gallart, F. (2005). Transpiration of mountain Pinus sylvestris L. and Quercus pubscens Wild forest stands measured with sap flow sensors in NE Spain. Hydroogy Earth Systems Sciences Discussions, 2, 1011-1046. https://doi.org/10.5194/hessd-2-1011-2005

Sebei, H., Albouchi, A., Rapp, M., \& EL Aouni, M. H. (2004). Productivité en phytomasse du chêne liège dans une séquence de dégradation de la subéraie à Cytise de Kroumirie (Tunisie). Annals of Forest Sciences, 61, 347-361. https://doi.org/10.1051/forest:2004028 
Thornton, P. E. (1998). Regional ecosystem simulation: Combining surface- and satellite-based observations to study linkages between energy and mass budgets ( $\mathrm{PhD}$ Thesis, University of Montana, Missoula, USA).

Tognetti, R., Longobucco, A., Miglienttai, F., \& Raschi, A. (1998). Transpiration and stomatal behaviour of Quercus ilex plants during the summer in a Mediterranean carbon dioxide spring. Plant, Cell and Environment, 21, 613-622. https://doi.org/10.1046/j.1365-3040.1998.00301.x

Vincke, C., Breda, N., Granier, A., \& Devillez, F. (2005). Evapotranspiration of declining Quercus robur (L.) stand from 1999 to 2001. I. Trees and forest floor daily evapotranspiration. Annals Forest Sciences, 62, $503-512$. https://doi.org/10.1051/forest:2005055

Vivin, P., \& Guehl, J. M. (1997). Changes in carbon uptake and allocation patterns in Quercus robur seedlings in response to elevated $\mathrm{CO}_{2}$ and water stress: an evaluation with 13C labeling. Annals Forest Sciences, 54, 597-610. https://doi.org/10.1051/forest:19970702

Wilkinson, M., Eaton, E. L., Broadmeadow, M. S. J., \& Morison, J. I. L. (2012). Inter-annual variation of carbon uptake by plantation oak woodland in south-eastern England. Biogeosciences, 9, 5373-5389. https://doi.org/ $10.5194 /$ bg-9-5373-2012

\section{Copyrights}

Copyright for this article is retained by the author(s), with first publication rights granted to the journal.

This is an open-access article distributed under the terms and conditions of the Creative Commons Attribution license (http://creativecommons.org/licenses/by/4.0/). 